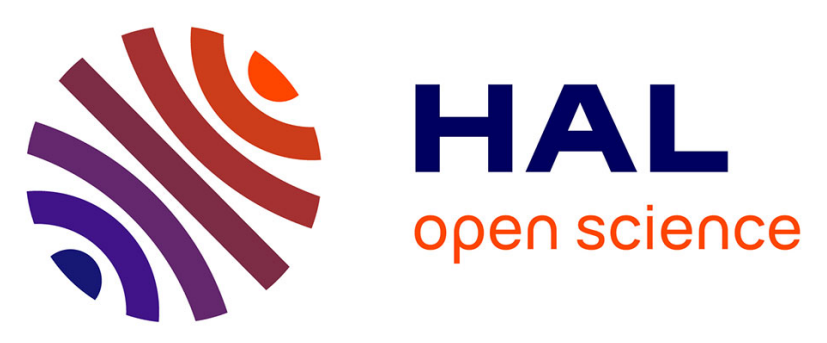

\title{
A click mediated route to a novel fluorescent pyridino-extended calix[4]pyrrole sensor: synthesis and binding studies
}

Ahmad Rifai, Nancy Alhaddad, Manale Noun, Ismail Abbas, Malek Tabbal, Rania Shatila, Francine Cazier-Dennin, Pierre-Edouard Danjou

\section{To cite this version:}

Ahmad Rifai, Nancy Alhaddad, Manale Noun, Ismail Abbas, Malek Tabbal, et al.. A click mediated route to a novel fluorescent pyridino-extended calix[4]pyrrole sensor: synthesis and binding studies. Organic \& Biomolecular Chemistry, 2019, 17 (23), pp.5818-5825. 10.1039/C9OB01106D . hal-02865850

\section{HAL Id: hal-02865850 \\ https://hal.science/hal-02865850}

Submitted on 22 Jul 2020

HAL is a multi-disciplinary open access archive for the deposit and dissemination of scientific research documents, whether they are published or not. The documents may come from teaching and research institutions in France or abroad, or from public or private research centers.
L'archive ouverte pluridisciplinaire HAL, est destinée au dépôt et à la diffusion de documents scientifiques de niveau recherche, publiés ou non, émanant des établissements d'enseignement et de recherche français ou étrangers, des laboratoires publics ou privés. 


\section{Journal Name}

\section{ARTICLE}

\section{A click mediated route to a novel fluorescent pyridino-extended calix[4]pyrrole sensor: synthesis and binding studies}

Received 00th January 20xx, Accepted 00th January 20xx

DOI: $10.1039 / x 0 x \times 00000 x$

\section{www.rsc.org/}

\author{
Ahmad Rifai ${ }^{b}$, Nancy AlHaddad ${ }^{a, b}$, Manal Noun ${ }^{b}$, Ismail Abbas ${ }^{c}$, Malek Tabbal ${ }^{d}$, Rania Chatila ${ }^{d}$, Francine Cazier- \\ Dennin $^{\mathrm{a}}$ and Pierre-Edouard Danjou* ${ }^{\mathrm{a}}$
}

A novel fluorescent aryl-extended phenoxycalix[4]pyrrole ditopic sensor, with enhanced cations recognition properties was efficiently synthesized via click chemistry and characterized through both molecular fluorescence and nuclear magnetic resonance spectroscopies. Results demonstrate the selectivity of this fluorescent sensor for fluoride when taking into account its interaction with anions, while its cation binding properties showed selectivity for iron, and sensing properties for several cations in dimethylsulfoxide. This work introduces a new ditopic receptor able to complex major environmentally relevant species and depicts the importance of the click chemistry in the introduction of new tetra-chromophoric calix[4]pyrrole binding platforms with specific photophysical properties.

\section{Introduction}

The recognition of anionic and cationic substrates has been one of the main focus of research in the field of supramolecular chemistry for the past few decades. [1] This was due to its pervasive role in the development of fluorescent sensors, [2] ion selective electrodes and biocompatible anions transporters. [3] For this purpose, continuous efforts were devoted to give a large variety of supramolecular architectures the ability to handle selective and efficient recognition for metals and non-metals in organic and aqueous solvents.

Calix[4]pyrroles are tetrapyrrolic supramolecules that were discovered first by Baeyer in 1886 as an octamethylcalix[4]pyrrole molecule (OMCP). [4] The fact that it bears an anion binding site on the level of its $\mathrm{NH}$ arrays was unknown until 1996, when it was discovered through a study carried by Sessler et al. [5] Since then, these molecules became notorious for their anion binding capacity [6] and especially for their preference towards the anionic fluorine among halide salts. [7] Taking into account such considerations conjointly to the relative ease of calix[4]pyrroles synthesis, these molecules were given advantage in terms of practical and

Ahmad Rifai and Nancy AlHaddad have contributed equally to this work.

a. Unité de Chimie Environnementale et Interactions sur le Vivant (UCEIV) Université du Littoral Côte d'Opale, 145 Avenue Maurice Schumann, MREI 1, 59140 Dunkerque, France.E-mail :danjou@univ-littoral.fr

b. Lebanese Atomic Energy Commission - National Council for Scientific Research B. P. 11- 8281, Riad El Solh 11072260 Beirut - Lebanon

c. Faculty of Sciences 1 - Lebanese University - Hadath - Lebanon.

d. American University of Beirut - Bliss Street Hamra - Beirut - Lebanon

Electronic Supplementary Information (ESI) available: [details of any supplementary information available should be included here]. See DOI: $10.1039 / x 0 \times x 00000 x$ commercial manipulations. [8] As a result, they were more and more studied and engaged in different biomedical, [9] chemical and environmental fields. Over the years, several improvements were made to this molecule in order to upgrade its selectivity and affinity to both anions and cations. Accordingly, new anionic [10] and ditopic ion pair sensors [11] were introduced. This was possible through the addition of new straps to the molecule via its $\beta$-position and/or its meso-carbons.

In 1999, a study carried by Bonomo et al. introduced a new mesorim OMCP derivative, called phenoxycalix[4]pyrrole or meso-tetramethyltetraKis(hydroxyphenyl)calix[4]pyrrole. [12] Its general synthesis relies on the condensation of pyrrole with $\mathrm{p}$ - or $\mathrm{m}$ hydroxyacetophenone and leads to various conformers with multiple sites acting as ready to functionalize or hosting sites. The major conformer was the so-called $\alpha \alpha \alpha \alpha$-phenoxycalix[4]pyrrole isomer (CP1), that was characterized by a pre-organized structure where all the phenol groups are set in the same direction in such a way that it formed an electron- $\pi$ rich cavity. [13] CP1 host medium was converted into other different molecules through addition or substitution made to its active hands (the carbon-rim or the phenol radical) producing new structures with enhanced molecular recognition properties. [7]

The term of click chemistry was introduced by Sharpless in 2001. [14] Among click reactions, the popular Huisgen cycloaddition consist of a reaction between azides and terminal alkynes, occurring in the presence of a copper catalyst and resulting in the formation of a 1,2,3-triazole entity. Click chemistry is favoured because of its reliability, specificity, synthetic simplicity and the addition of a triazole fluorescent strap that plays a twofold role of cation or anion chelation site as well as being a platform that allows the addition of new functionalities to the receptor. [15] 
Nevertheless, the molecular fluorescence properties of triazole remain underexploited.

While previous studies [6] [10] [11] were found to introduce clickfunctionalized calix[4]pyrroles, few [16] employed click chemistry to develop $\alpha \alpha \alpha \alpha$-phenoxycalix[4]pyrroles and none investigated its binding properties for triazole molecular fluorescence.

In 2017, a study of Sessler et al. introduced two new functionalized phenoxycalix[4]pyrroles using click chemistry. Both acted as ion pair receptors binding simultaneously $\mathrm{Fe}^{2+}$ and $\mathrm{F}^{-}$, however no investigations were performed with cations other than $\mathrm{Fe}^{2+}$. This study opened the door for a new type of functionalization to arylextended phenoxycalix[4]pyrroles. [16] The addition of longchained and aromatic-electron rich straps gave the molecule extraction properties towards $\mathrm{FeF}_{2}$ and specific interfacial molecular interactions.

In that sense, this paper addresses a study of the synthesis of a new fluorescent pyridine-extended $\alpha \alpha \alpha \alpha$-phenoxycalix[4]pyrrole sensor, CP3, via click chemistry (Figure 1 ) and its ionic recognition properties in dimethylsulfoxide (DMSO). The functionalization of this molecule was based on the expansion of its aromatic arms via the addition of two new entities: a triazole strap and a pyridine moiety. This latter represents to the best of our knowledge the first calix[4]pyrrole molecule studied for its molecular fluorescence properties towards ionic species. The fluorescent identity of this ligand, allowed a first step for the use of fluorescent phenoxycalix[4]pyrroles for metals detection due to the superiority of the molecular fluorescence spectroscopy over other common methods. In fact, this method possesses high sensitivity allowing the use of fluorescent entities, as often as possible in submicromolar concentrations, a non-destructive analysis, a rapid response, a relative ease of manipulation and a low cost compared to other tools. [17] Thus, characterizations and investigations were achieved using molecular fluorescence, time-resolved fluorescence and nuclear magnetic resonance spectroscopies. Results depicted that CP3 acts as a ditopic receptor capable of selectively complexing fluoride on the level of its pyrrolic ring. Moreover, two major environmentally relevant species $\mathrm{Fe}^{2+}, \mathrm{Fe}^{3+}$ on the level of its nitrogen-crowded extended aromatic arms as well as recognition and sensing properties for other cations, and more specifically for $\mathrm{Hg}^{2+}$, were detected.

In addition to these latter methods, a brief and one of the rare type of investigations applied on supramolecules was carried through Time-of-Flight Secondary Ion Mass Spectrometry (TOF-SIMS) in order to build a more detailed study of CP3's molecular recognition towards metals and anionic species.
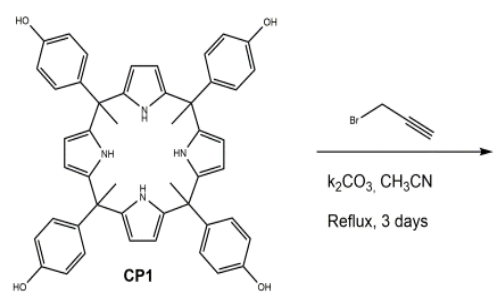

Figure 1: Synthesis of the fluorescent compound CP3

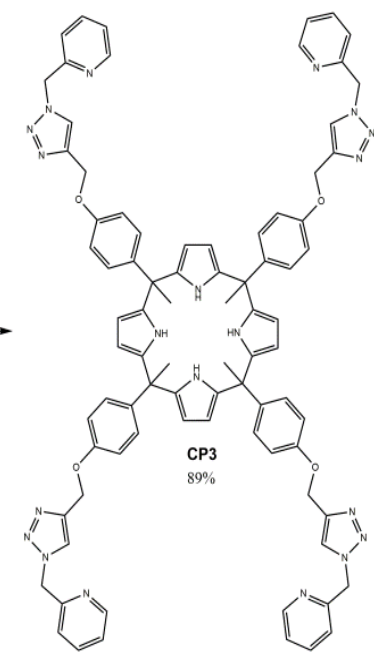

molecule was fully characterized by ${ }^{1} \mathrm{H},{ }^{13} \mathrm{C}$ NMR spectroscopy (see supplementary data Figure 1 to 8 ) and TOF-SIMS.

\section{Synthesis of $\mathrm{CP} 3$ receptor}

The overall synthesis of CP3 receptor was depicted in Figure 1. CP2 was first synthesized via a reaction of CP1 with propargyl bromide in acetonitrile. Although this compound was already described in the study of Sessler et al. in 2017 [16] with a yield of $65 \%$, the proposed protocol reports an improved yield of $80 \%$. CP2, including a ready-to-click alkyne platform, was used next to anchor a 2pyridino moiety through an azide-alkyne condensation with 2(azidomethyl)pyridine synthesized by microwave irradiation. [18] Based on previous studies in which several conditions were tested in the aim of optimizing the click reaction conditions, [15] the reaction was carried in DMSO in the presence of copper iodide and triethylamine to grant CP3 with $89 \%$ yield. The synthesized

\section{Optical properties of CP3}

Owing to the presence of four 1,2,3-triazole chromophores [19] in CP3, absorbance, fluorescence spectroscopy, time-resolved fluorescence and quantum yield investigations were undertaken in order to understand the photophysical properties of CP3 and study its complexing and recognition capacities towards several ionic guests in DMSO.

Molecular fluorescence emission and excitation spectra were recorded in DMSO and it showed that CP3 exhibited a maximal emission at $446 \mathrm{~nm}$ upon excitation at $300 \mathrm{~nm}$ (see supplementary data Figure 9). Quantum yield experiments for CP3 were carried in comparison with an anthracene reference standard [20] and was found to be 0.02 which is fully coherent with other values reported 
in the literature for similar pyridin-2-yl-1,2,3-triazole supramolecular platforms (ß-cyclodextrins and calix[4]arenes). [21 ]

Time-resolved fluorescence of CP3 was investigated. Fluorescence decays of CP3 in DMSO were recorded upon excitation using a NanoLED light source $(330 \mathrm{~nm}$ ) (see supplementary data Figure 10). A sum of four exponentials was required in order to obtain an adequate fit of the fluorescence decay for a channel width of $82 \mathrm{~ns}$ and thus an average decay time of approximately 7 ns and a satisfactory chi-squared value of 1.19. It is difficult to explain physically the presence of several decays as it could be attributed to the presence of residual protonated forms of CP3 or to the heterogeneity of the microenvironments of the fluorophores.

\section{Anions recognition study}

Upon addition of anions, ${ }^{1} \mathrm{H}$ NMR and molecular fluorescence titrations clearly indicate that CP3 was able to discriminate between tetrabutylammonium salts of anions to recognize and bind selectively the fluoride over chloride, bromide, iodide and hydrogensulfate (see supplementary data Figure 11 and 12). The design of CP3 resulted in a deep aromatic "fluoride only" recognition cavity. ${ }^{1} \mathrm{H}$ NMR titrations of CP3 with TBAF (Figure 2) records the chemical shift and shows the progressive disappearance of the free ligand signals in favor of the new fluorine-complexed ligand. While new resonances appeared upon addition of 3 TBAF equivalents, total complexation was achieved upon addition of 11 equivalents and was evidenced by the disappearance of the $\mathrm{NH}$ singlet resonance at $9.4 \mathrm{ppm}$ in favor of a new doublet resonance at $12.6 \mathrm{ppm}(\mathrm{H}-\mathrm{F} \mathrm{J}=46 \mathrm{~Hz})$. These changes demonstrate the hydrogen bond formation between the fluorine and the pyrrolic ring, leading to the reorganization of the macrocycle that gets locked into a cone conformation when all the four $\mathrm{NH}$ pyrrolic functions get involved in the complexation. [3] [13] [22]

In fact, the whole complexation process was governed by several phenomena. Upfield chemical shifts were recorded mainly for the phenolic entity $(\Delta \delta=0.25$ and $0.14 \mathrm{ppm})$ : during the complexation process, fluorine took advantage of the $\pi$ aromatic systems shielding the pyrrolic cavity to tighten their bonding by additional non-covalent anion- $\pi$ interactions. This result indicates that fluorine, once complexed by CP3 will occupy the upper rim of the pyrrolic cavity surrounded by its extended aromatic arms. [23]

In order to determine the stoichiometry of the predominant complex, a Job plot was carried in d6-DMSO in a total concentration of $5 \mathrm{mM}$ (see supplementary data Figure 13). This latter showed a maximum at CP3's molar fraction close to 0.5 , demonstrating that the predominant complex has a binding stoichiometry of 1:1.

While most calix[4]pyrroles are well known to complex fluorine, as expected, CP3 was able to bind selectively fluoride considered toxic to the environment and the human health. In fact, this latter occurs naturally in the environment, but was also produced by different anthropic activities. Different sources, like diet, water and mainly tooth brushing could lead to ingesting relatively high amounts of fluorine. Despite its preventive role of protecting teeth from dental cavities, potentially serious health risks may result upon its ingestion, in the form of dental fluorosis and osteoporosis. [8] [24]

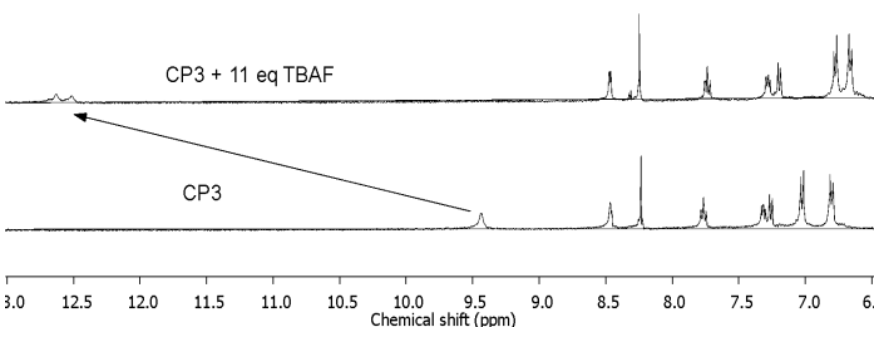

Figure 2: Partial ${ }^{1} \mathrm{H}$ NMR spectra of CP3 with Tetra-butylammonium fluorine (TBAF) in d6-DMSO.

Following ${ }^{1} \mathrm{H}$ NMR titrations, anions selectivity of CP3 was investigated as well by molecular fluorescence spectroscopy. As expected, fluoride anion induced a drastic decrease of fluorescence intensity of $36 \%$ while other anions presented minor variations. The small decrease of fluorescence upon addition of iodide could be attributed to the heavy atoms effect [25] usually encountered with this anion.

\section{Cations recognition study}

Initially, this ligand was designed in order to bring new active electron- $\pi$ rich sites close to the phenolic parent moieties, in order to access better molecular recognition. For this purpose, two potential nitrogen-crowded straps (i.e. triazole units) were added to CP1. Through this modification, new cations recognition and signaling capacities were created.

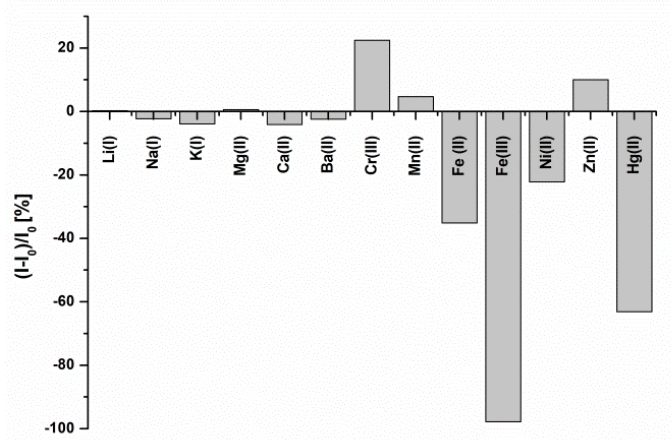

Figure 3: Change in fluorescence emission of CP3 $\left(5^{*} 10-5 \mathrm{M}, \lambda_{\mathrm{ex}}=\right.$ $300 \mathrm{~nm}, \mathrm{DMSO}$ ) upon addition of 10 equivalents of various metal cations as perchlorate salts. 


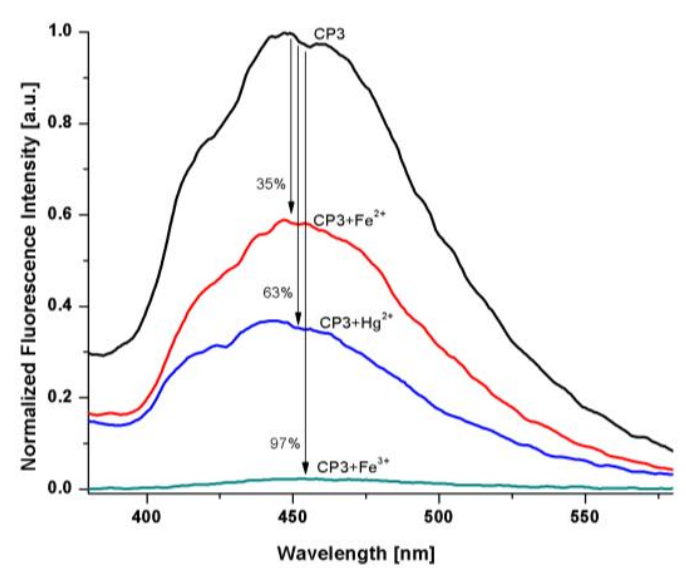

Figure 4: Fluorescence quenching of CP3 $(5 * 10-5 \mathrm{M}, \lambda \mathrm{ex}=300 \mathrm{~nm}$, DMSO) upon addition of 10 equivalents of various metal cations as perchlorate salts.

\section{Investigations of CP3 fluorescent photophysical properties upon metal recognition}

Fluorescence variations were investigated by fluorimetric titrations at constant CP3 concentration ( $50 \mathrm{mM}$ ) by following the molecular fluorescence emission intensity at $446 \mathrm{~nm}$. Figure 3 shows the variation of fluorescence emission after addition of 10 equivalents of thirteen different metal cations to a solution of CP3. Interestingly enough, only three metals $\mathrm{Fe}^{2+}, \mathrm{Fe}^{3+}$ and $\mathrm{Hg}^{2+}$ induced a significant quenching (over $25 \%$ ) of the fluorescence intensity: $97 \%$ for $\mathrm{Fe}^{3+}, 35 \%$ for $\mathrm{Fe}^{2+}$ and $63 \%$ for $\mathrm{Hg}^{2+}$ (Figure 4). Plus, the addition of $\mathrm{Ni}^{2+}$ led to a smaller quenching of $22 \%$. While both $\mathrm{Cr}^{3+}$ and $\mathrm{Zn}^{2+}$ produced a moderate enhancement of respectively $22 \%$ and $10 \%$, other metals gave no or negligible responses of CP3.

In order to better understand the underlying mechanisms leading to the fluorescence quenching upon addition of metallic species of CP3 in solution, the Stern-Volmer method combined with measurements of fluorescence lifetimes was undertaken. It allowed to distinguish between dynamic, static and both static and dynamic quenching for the four metallic quenchers. As a result, an increasing slope of $\tau_{0} / \tau$ plot as a function of increasing $\mathrm{Hg}^{2+}$ and $\mathrm{Ni}^{2+}$ concentrations indicates the pure dynamic nature of the decrease in fluorescence. For those cations, quenching occurs when excited fluorophores experience contacts with these species and therefore non-radiative transitions to the ground state were facilitated. Conversely, experiments with $\mathrm{Fe}^{2+}$ indicated a purely static quenching i.e a linear relation was observed for $F_{0} / F$ plot against increasing concentration of $\mathrm{Fe}^{2+}$ without evolution of fluorescence lifetime. A photo-induced electron transfer probably occurs upon chelation of $\mathrm{Fe}^{2+}$ with electrons rich moieties of CP3. Concerning the $97 \%$ decrease of fluorescence intensity of CP3 by addition of 10 equivalents of $\mathrm{Fe}^{3+}$, unchanged $\tau_{0} / \tau$ ratio and quadratic dependency of $F_{0} / F$ with an upward curvature shape were observed, indicating the presence of both dynamic and static quenching. This duality could contribute to explain the results obtained in the previous fitting experiments. As for the two moderate fluorescence emission enhancements caused by the addition of $\mathrm{Cr}^{3+}$ and $\mathrm{Zn}^{2+}$ it may be due to chelation-enhanced-fluorescence as previously reported on similar structure including pyridyl groups and triazole units [26].

A Good correlation between experimental and calculated data [27] was obtained for $\mathrm{Fe}^{2+}$ assuming the 1:1 host/guest complex stoichiometry usually observed for this kind of compounds. Remarkably the 1:1 model could not explain the quenching of CP3 fluorescence emission by $\mathrm{Fe}^{3+}$ while a coexistence of $1: 1$ and 1:2 complexes perfectly fit the observed quenching. Association constants were found to be $2400 \pm 700$ and $34000 \pm 5000$ for $\mathrm{Fe}^{2+}$ and $\mathrm{Fe}^{3+}$ respectively (see supplementary data Figure 14 and 15).
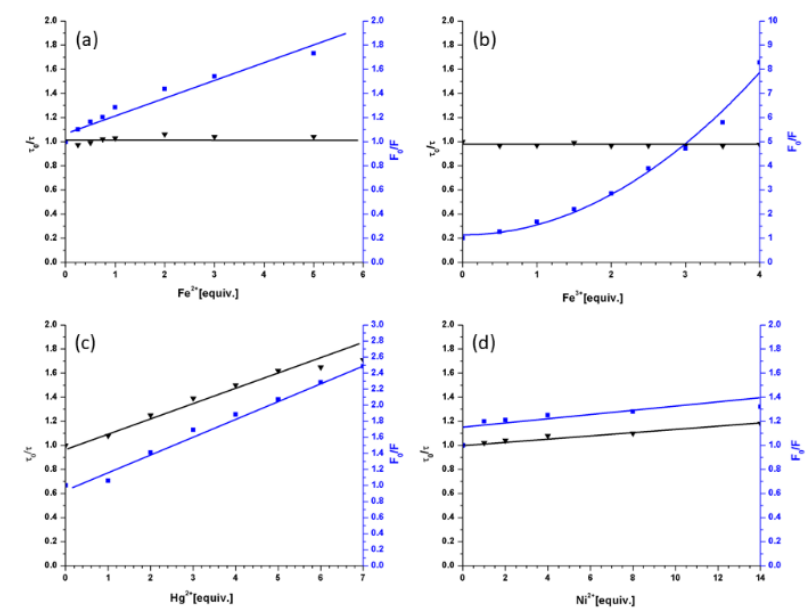

Figure 5: Fluorescence quenching of CP3 upon addition of (a) $\mathrm{Fe}^{2+}$, (b) $\mathrm{Fe}^{3+}$, (c) $\mathrm{Hg}^{2+}$ and (d) $\mathrm{Ni}^{2+}\left(\mathrm{F} / \mathrm{F}_{0}\right.$, blue square; $\tau_{0} / \tau$ black triangle)

\section{Time-of flight secondary ion mass spectrometry (TOF-SIMS)} study

CP3 was detected in both positive and negative ionization emission modes with a molecular formula proposed as $\mathrm{C}_{84} \mathrm{H}_{77} \mathrm{~N}_{20} \mathrm{O}_{4}{ }^{+}$for $[\mathrm{M}+\mathrm{H}]^{+}\left(\mathrm{m} / \mathrm{z}\right.$ 1429.6461) and $\mathrm{C}_{84} \mathrm{H}_{75} \mathrm{~N}_{20} \mathrm{O}_{4}^{-}$for $[\mathrm{M}-\mathrm{H}]^{-}(\mathrm{m} / \mathrm{z}$ 1427.6292). Figure 6 , Figure 7 and Figure 8 represent the comparison of CP3s' spectrum with three other different spectra, each representing $\mathrm{CP}$ upon its interaction respectively with $\mathrm{F}^{-}$ (TBAF), $\mathrm{Fe}^{3+}$ and $\mathrm{Hg}^{2+}$ (as perchlorates). Results show the complexation of CP3 with fluorine with a ratio of 1:3 (Figure 6) and $\mathrm{a}[\mathrm{M}+2 \mathrm{Fe}]^{+}$was detected for its interaction with $\mathrm{Fe}^{3+}$ (Figure 7).

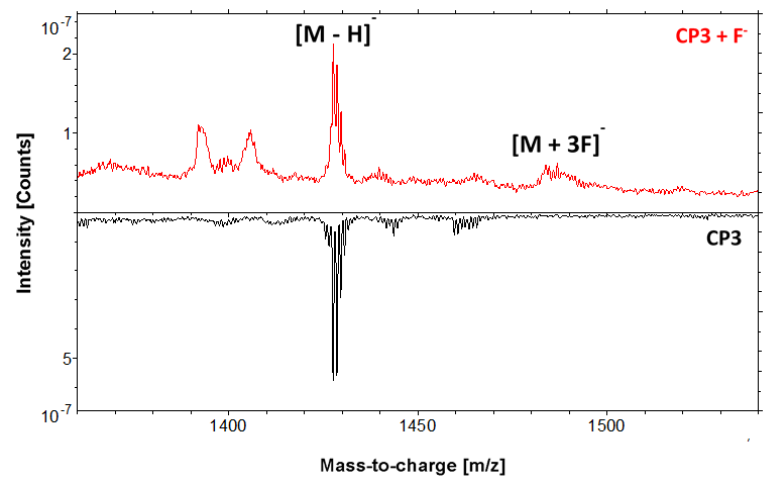

Figure 6: Part of negative ion mass spectra of "CP3" (in black) and "CP3+ fluorine" (in red) samples between m/z 1460 and m/z 1540. The spectra are normalized to the total primary ion dose. 


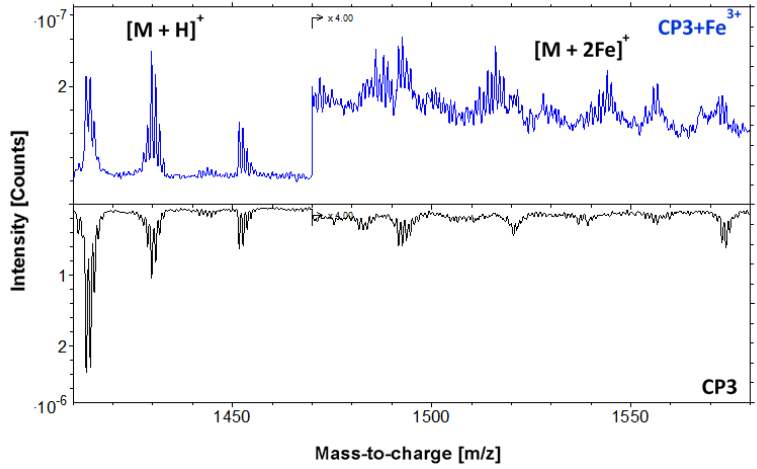

Figure 7: Part of positive ion mass spectra of "CP3 (in black) and "CP3+ iron" (in blue) samples between $\mathrm{m} / \mathrm{z} 1410$ and $\mathrm{m} / \mathrm{z}$ 1580. The spectra are normalized to the total primary ion dose.

As for Figure 8, when comparing between the mass spectra of pure CP3 and CP3 with mercury, an emission of $\mathrm{Hg}^{2+}(\mathrm{m} / \mathrm{z} 201.97$ for main isotope) in the positive ionisation mode was observed. Nevertheless no emission of pure $\mathbf{C P 3}$ neither as $[\mathrm{M}+\mathrm{H}]^{+}$, nor as $[\mathrm{M}+\mathrm{Hg}]^{+}$or $[\mathrm{M}+\mathrm{nHg}]^{+}$was detected; yet significant changes in the peaks of the mass spectra were observed after addition of the mercury salt to the CP3. This result is in agreement with molecular fluorescence results that indicates the absence of static interactions between $\mathrm{CP} 3$ and $\mathrm{Hg}^{2+}$

In order to understand whether these ratios define intra and/or intermolecular interactions, the polymeric distribution as well as the absence of different reputable $\mathrm{m} / \mathrm{z}$ peaks in the mass spectra of CP3 with these ions, additional analyses and optimized experimental conditions are required. However detecting the calix[4]pyrrole molecule on TOF-SIMS, to the best of our knowledge was not reported in the literature and was rarely mentioned in the field of supramolecular chemistry. More detailed studies will be carried through TOF-SIMS in order to further our knowledge on the behaviour of CP3 towards ionic species in different experimental conditions.

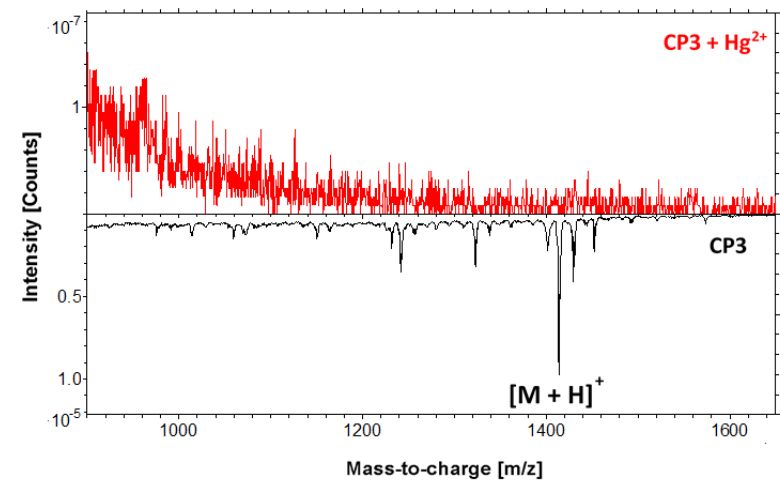

Figure 8: Part of positive ion mass spectra of "CP3" (in black) and "CP3 + mercury" (in red) samples between m/z 250 and m/z 1645 . The spectra are normalized to the total primary ion dose.

\section{Conclusions}

A novel aryl-extended phenoxycalix[4]pyrrole derivative CP3 was efficiently synthesized owing to click chemistry in a twostep protocol from native phenoxycalix[4]pyrrole. This receptor presents one anion chelation site on the level of its pyrrolic ring and a cation binding site on the level of its aromatic arms. The 1,2,3 triazole "click-added" linker confers on this receptor new physico-chemical fluorescent properties which allowed its study by molecular fluorescence spectroscopy. CP3 proved to be a turn-off fluorescent sensor upon detection of fluoride, iron and mercury. Therefore, fluorescence quenching mechanisms were evaluated using Stern-Volmer formalism coupled with time-resolved fluorescence and it indicated that CP3 is able to form stable complexes with iron cations while purely collisional effects were observed for mercury and nickel. Moreover, this study introduces the first evaluation of supramolecules complexation behaviour using time-of flight secondary ion mass spectrometry. All of these findings make this fluorescent ditopic sensor a potential material that could serve for cations recognition, but also as an ion-selective sensor for fluorine. Our future effort will be devoted to improving selectivity of phenoxycalix[4]pyrrole sensors.

\section{Experimental Section}

\section{Procedures and characterization}

\section{Synthesis of 2-(azidomethyl)pyridine}

2-(Chloromethyl)pyridine hydrochloride $(1,0 \mathrm{~g}, 6.10 \mathrm{mmol})$ was suspended in dichloromethane $(30 \mathrm{~mL})$ and neutralized by a saturated solution of sodium hydrogen carbonate $(3 * 15 \mathrm{~mL})$. The organic phase was later evaporated and the desired product was obtained as an orange oil. After addition of $20 \mathrm{~mL}$ of water and sodium azide $(0.66 \mathrm{~g}, 10.15 \mathrm{mmol})$ to the aforementioned oil, the resulting mixture was placed in a sealed microwave vessel and irradiated (biotage initiator) for one hour at $120{ }^{\circ} \mathrm{C}$. Then it was extracted with diethyl ether $\left(3^{*} 25 \mathrm{~mL}\right)$ and evaporated to dryness. The azido compound was finally obtained as a consistent oil in a $61 \%$ yield. ${ }^{1} \mathrm{H}$ NMR $\left(400 \mathrm{MHz}, \mathrm{CDCl}_{3}\right): \delta=8.62-8.53(\mathrm{~m}, 1 \mathrm{H}), 7.74-$ $7.65(\mathrm{~m}, 1 \mathrm{H}), 7.32(\mathrm{t}, J=6.1 \mathrm{~Hz}, 1 \mathrm{H}), 7.25-7.20(\mathrm{~m}, 1 \mathrm{H}), 4.47(\mathrm{~s}$, $\left.\mathrm{CH}_{2}-\mathrm{N}_{3}, 2 \mathrm{H}\right)$.

Caution! Although no problem has been encountered, it is noted that azide derivatives are potentially explosive. They should be handled with care.

\section{Synthesis of CP2 (CP-alkyne)}

CP1 (330 mg, $0.45 \mathrm{mmol}$ ) and $\mathrm{K}_{2} \mathrm{CO}_{3}(750 \mathrm{mg}, 5.43 \mathrm{mmol}$ ) were suspended in acetonitrile $(30 \mathrm{~mL})$ and stirred for 30 minutes in order to activate the calix[4]pyrroles. A mixture of Propargyl bromide $80 \%$ in toluene $(270.7 \mu \mathrm{L})$ was added slowly and the mixture was refluxed for 3 days. After cooling the solution, the solvent was removed in vacuo. The resulting product was dissolved in $30 \mathrm{~mL}$ of dichloromethane and washed with water, a solution of $\mathrm{HCl}(1 \mathrm{M})$ and a saturated solution of $\mathrm{NaHCO} 3(2 * 15 \mathrm{~mL}$ each time). The organic phase was evaporated affording a brown powder in an $80 \%$ yield. ${ }^{1} \mathrm{H}$ NMR $\left(400 \mathrm{MHz}, \mathrm{CDCl}_{3}\right) \delta 7.61(\mathrm{~s}, 1 \mathrm{H}), 7.04(\mathrm{~d}, J=8.8 \mathrm{~Hz}$, 
2H), $6.84(\mathrm{~d}, J=8.9 \mathrm{~Hz}, 2 \mathrm{H}), 5.74(\mathrm{~d}, J=2.0 \mathrm{~Hz}, 2 \mathrm{H}), 4.66(\mathrm{~d}, J=2.3$ $\mathrm{Hz}, 2 \mathrm{H}), 2.54(\mathrm{t}, J=2.3 \mathrm{~Hz}, 1 \mathrm{H}), 1.94(\mathrm{~s}, 3 \mathrm{H}) .{ }^{13} \mathrm{C} N M R(101 \mathrm{MHz}$ $\left.\mathrm{CDCl}_{3}\right) \delta 156.2,141.3,136.8,128.7,114.0,106.3,78.8,75.7,56.0$, $44.2,28.4$.

\section{Synthesis of CP3 (CP-Click 2-pyridine)}

A solution of the alkyne calix[4]pyrrole CP2 (300 mg, $0.34 \mathrm{mmol})$ in dimethylsulfoxide $(25 \mathrm{~mL})$ was stirred and 2-(azidomethyl)pyridine (365 mg, $2.72 \mathrm{mmol}$ ), copper iodide (325 mg, $1.71 \mathrm{mmol}$ ) and triethylamine ( $310 \mu \mathrm{L}, 2.24 \mathrm{mmol})$ were added. The mixture was left overnight at $50^{\circ} \mathrm{C}$. After cooling, the mixture was quenched slowly in water $(40 \mathrm{~mL})$. Therefore, a greenish aqueous phase was obtained, and filtered, giving a dark green solid. This latter was mixed with $30 \mathrm{~mL}$ of dichloromethane, to be washed later by ammonia $10 \%$ until the disappearance of the blue coloration of the aqueous phase. After that, $\mathrm{HCl} 1 \mathrm{~N}$ was added to the organic phase and $\mathbf{C P} 3$ precipitates as a light green solid which was then washed with $\mathrm{NaHCO}_{3}(2 * 30 \mathrm{~mL})$ and $\mathrm{H}_{2} \mathrm{O}(2 * 30 \mathrm{~mL})$. The $\mathrm{CP} 3$ was obtained as a green powder in a $89 \%$ yield after being purified over silica column chromatography in a mixture of dichloromethane and methanol (10:1). 1H NMR (500 MHz, DMSO): $\delta=9.43(\mathrm{~s}, \mathrm{NH}, 1 \mathrm{H})$, $8.47-8.45(\mathrm{~m}$, pyridine, $1 \mathrm{H}), 8.24(\mathrm{~d}, J=6.5 \mathrm{~Hz}$, triazole, $1 \mathrm{H}), 7.76$ (td, $J=7.7$, pyridine, $1.8 \mathrm{~Hz}, 1 \mathrm{H}), 7.33-7.25(\mathrm{~m}$, pyridine, $2 \mathrm{H}), 7.04$ - $7.02(\mathrm{~d}, J=8.9 \mathrm{~Hz}$, phenolic $\mathrm{H}, 2 \mathrm{H}), 6.81-6.79(\mathrm{~d}, J=8.7 \mathrm{~Hz}$, phenolic $\mathrm{H}, 2 \mathrm{H}$ ), $5.94\left(\mathrm{~s}, \mathrm{CH}_{2}\right.$-pyridine, $\left.2 \mathrm{H}\right), 5.67$ (s , pyrrolic $\left.\mathrm{H}, 2 \mathrm{H}\right)$, $5.07\left(\mathrm{~s}, \mathrm{O}-\mathrm{CH}_{2}, 2 \mathrm{H}\right), 1.75\left(\mathrm{~s}, \mathrm{CH}_{3}, 3 \mathrm{H}\right) .{ }^{13} \mathrm{C}$ NMR (125 MHz, DMSO) $\delta$ 156.9, 154.9, 149.5, 149.4, 142.8, 142.5, 137.4, 127.9, 125.5, 125.4, 123.3, 122.3, 122.3, 114.5, 104.6, 61.2, 54.4, 43.5, 31.31. HRMS (TOF-SIMS) calc for $\mathrm{C}_{84} \mathrm{H}_{77} \mathrm{~N}_{20} \mathrm{O}_{4}^{+} \mathrm{m} / \mathrm{z} \quad 1429,6431$ found $\mathrm{m} / \mathrm{z}$ 1429.6461.

\section{General procedures for ${ }^{1} \mathrm{H}$ NMR and fluorescence titrations}

${ }^{1} \mathrm{H}$ and ${ }^{13} \mathrm{C}$ NMR measurements were recorded at $298 \mathrm{~K}$. CP3 solutions of well-determined concentrations $\left(10^{-3} \mathrm{M}\right)$ were prepared in deuterated dimethylsulfoxide. Investigations concerning CP3 and its interactions with anions (fluoride, chloride, bromide, iodide and hydrogen sulfate as tetra-n-butylammonium salts) were carried by several titrations where the anions were prepared in the same solvent dissolving CP3 in the same concentration conditions $(10$ $\left.{ }^{3} \mathrm{M}\right)$. Upon addition of the anion salts, chemical shifts of the free and the complexed ligand were recorded.

As for the cations binding capacity $\left(\mathrm{Li}^{+}, \mathrm{Na}^{+}, \mathrm{K}^{+}, \mathrm{Mg}^{2+}, \mathrm{Ca}^{2+}, \mathrm{Ba}^{2+}\right.$, $\mathrm{Cr}^{3+}, \mathrm{Mn}^{2+}, \mathrm{Fe}^{2+}, \mathrm{Fe}^{3+} \mathrm{Zn}^{2+}, \mathrm{Ni}^{2+}, \mathrm{Hg}^{2+}$ as perchlorate salts), $\mathrm{CP} 3$ was studied by molecular fluorescence spectroscopy in DMSO $\left(5 * 10^{-5}\right.$ M).

\section{Time-of flight secondary ion mass spectrometry (TOF-SIMS) Parameters}

The solid samples were firstly dissolved in dichloromethane then filtered; the liquid parts were used for TOF-SIMS analyses. For each sample a volume of $20 \mu \mathrm{L}$ was deposited on silicon substrate. All experiments and analyses were done in triplicate.

The analyses were performed by TOF-SIMS $\mathrm{V}$ mass spectrometer (ION-TOF GmbH, Munster, Germany) in the Lebanese Atomic Energy Commission-NCSR (Lebanon). The instrument was equipped with bismuth and argon clusters sources and a reflectron time-offlight analyzer. $\mathrm{Bi}_{3}{ }^{+}$clusters ion beam at $25 \mathrm{keV}$ hitting the sample surfaces with a $45^{\circ}$ angle of incidence were selected for the analyses [28]. The spectroscopy mode, also called high current bunched mode was chosen for the analyses with a spatial resolution of $2 \mu \mathrm{m}$ and $\mathrm{M} / \Delta \mathrm{M}$ (Full Width at Half Maximum) 2000-8000 [29]. The secondary ions were extracted and post-accelerated to $10 \mathrm{keV}$ before hitting a single micro-channel plate detector. For each sample, three replicates were analyzed. Areas of $500 \mu \mathrm{m} * 500 \mu \mathrm{m}$ $(256 * 256$ pixels) in positive and negative emission modes were explored using a primary ion dose intensity of $5 \times 10^{11}$ ions $/ \mathrm{cm}^{2}$ for each polarity. Mass spectra were processed using Surface Lab 6.8 software (ION-TOF GmbH, Münster, Germany) and internally calibrated using $\mathrm{H}^{+}, \mathrm{H}_{2}^{+}, \mathrm{H}_{3}{ }^{+}, \mathrm{C}^{+}, \mathrm{CH}^{+}, \mathrm{CH}_{3}{ }^{+}, \mathrm{C}_{2} \mathrm{H}_{3}{ }^{+}$and $\mathrm{C}_{3} \mathrm{H}_{5}^{+}$in positive mode and $\mathrm{H}^{-}, \mathrm{C}^{-}, \mathrm{CH}^{-}, \mathrm{C}_{2}^{-}, \mathrm{C}_{2} \mathrm{H}^{-}, \mathrm{C}_{3}^{-}, \mathrm{C}_{3} \mathrm{H}^{-}, \mathrm{C}_{4}^{-}$and $\mathrm{C}_{4} \mathrm{H}^{-}$in negative mode, respectively.

\section{Conflicts of interest}

There are no conflicts to declare

\section{Acknowledgements}

The authors would like to thank the Lebanese Council for Scientific Research (CNRS-L), the International Atomic Energy Agency (IAEA) and the Université du Littoral Côte d'Opale (ULCO) for supporting this work and for a research fellowship. Région "Hauts-de-France " and the Ministère de l'Enseignement Supérieur et de la Recherche (CPER IRENE), and the European Fund for Regional Economic Development, are as well acknowledged for their financial support.

Authors are also grateful to the "Centre Commun de Mesures" of the ULCO for the access to HRMS and would like to thank Pr. David Landy for his help with the constants' calculation.

\section{References}

${ }^{1}$ (a) J. M. Lehn, Science, 1985, 227, 849-856; (b) I. Saha, J. T. Lee, and C.-H. Lee, Eur. J. Org. Chem., 2015, 18, 3859-3885

2 A. P. de Silva, H. Q. N. Gunaratne, T. Gunnlaugsson, A. J. M. Huxley, C. P.mMcCoy, J. T. Rademacher, and T. E. Rice, Chem. Rev., 1997, 97, 1515-1566

3 J. L. Sessler, P. Anzenbacher, K. Jursíková, H. Miyaji, J. W. Genge, N. A. Tvermoes, and V. Král, Pure and Appl. Chem., 1998, 70, 24012408.

${ }^{4}$ A. Baeyer, Berichte Der Deutschen Chemischen Gesellschaft, 1886, 19, 2184-2185.

${ }^{5}$ P. A. Gale, J. L. Sessler, V. Král and V. Lynch, J. Am. Chem. Soc., 1996, 118, 5140-5141.

${ }^{6}$ (a) H. Miyaji, W. Sato and J. L. Sessler, Angew. Chem. Int. Ed., 2000, 112, 1847-1850; (b) J. L. Sessler, D. E. Gross, W.-S. Cho, V. M. Lynch, F. P.Schmidtchen, G. W. Bates, and P. A. Gale, J. Am. Chem. Soc., 2006, 128, 12281-12288; (c) M. Yano, C. C. Tong, M. E.Light, F. P. Schmidtchen, and P. A. Gale, Org. Biomol. Chem., 2010,8, 43564363.

${ }^{7}$ (a) S. Camiolo and P. A. Gale, Chem. Commun., 2000, 13, 11291130; (b) C. J. Woods, S. Camiolo, M. E. Light, S. J. Coles, M. B. Hursthouse, M. A. King and J. W. Essex, J. Am. Chem. Soc., 2002, 
124, 8644-8652; (c) A. F. Danil de Namor, I. Abbas and H. H. Hammud, J. Phys. Chem. B, 2007, 111, 3098-3105.

${ }^{8}$ A. F. Danil de Namor and I. Abbas, In A. Tressaud (Ed.), Advances in Fluorine Science, 2006, 2, 81-119.

${ }^{9}$ S.-K. Ko, S. K. Kim, A. Share, V. M. Lynch, J. Park, W. Namkung and I. Shin, Nat. Chem., 2014, 6, 885.

${ }^{10}$ M. G. Fisher, P. A. Gale, J. R.Hiscock, M. B.Hursthouse, M. E. Light, F. P. Schmidtchen and C. C. Tong, 2009, Chem. Commun., 0, 30173019.

${ }^{11}$ (a) C. C. Tong, R. Quesada, J. L. Sessler and P. A. Gale, Chem. Commun., 2008, 0, 6321-6323; (b) M. Ciardi, A. Galán and P. Ballester, J. Am. Chem. Soc., 2015, 137, 2047-2055.

12 L. Bonomo, E. Solari, G.Toraman, R. Scopelliti, C. Floriani and M. Latronico, Chem. Commun., 1999, 0, 2413-2414.

13 P. Anzenbacher, K. Jursíková, V. M. Lynch, P. A. Gale and J. L. Sessler, J. Am. Chem. Soc., 1999, 121, 11020-11021.

${ }^{14}$ H. C. Kolb, M. G. Finn and K. B. Sharpless, Angew. Chem. Int. Ed., 2001, 40, 2004-2021.

${ }^{15}$ (a) J. E. Moses and A. D. Moorhouse, Chem. Soc. Rev., 2007, 36, 1249-1262; (b) L.-Y. Wu, Y.-X. Xie, Z.-S. Chen, Y.-N. Niu and Y.-M. Liang, Synlett, 2009, 9, 1453-1456; (c) D. Ghosh, S. Rhodes, K. Hawkins, D. Winder, A. Atkinson, W. Ming and S. Landge, New J. Chem., 2015, 39, 295-303.

${ }^{16}$ X. Chi, G. M. Peters, F. Hammel, C. Brockman and J. L. Sessler, J. Am. Chem. Soc., 2017, 139, 9124-9127.

${ }^{17}$ J. J. Santana Rodríguez, R. Halko, J. R. Betancort Rodríguez and J. J. Aaron, Anal. and Bioanal. Chem., 2006, 385, 525-545.

${ }^{18}$ Y. Ju, D. Kumar and R. S. Varma, J. Org. Chem., 2006, 71, 66976700.

19 (a) Ghosh, S. Rhodes, K. Hawkins, D. Winder, A. Atkinson, W. Ming, C. Padgett, J. Orvis, K. Aiken and S. Landge, New J. Chem., 2015, 39, 295-303. (b) Mallard-Favier, P. Blach, F. Cazier and F. Delattre, Carbohydr. Res., 2009, 344, 161-166.

20 "A Guide to Recording Fluorescence Quantum Yields" by HORIBA Jobin Yvon IBH Ltd.

${ }^{21}$ V. Souchon, S. Maisonneuve, O. David, I. Leray, J. Xie and B. Valeur, Photochem. Photobiol. Sci., 2008, 7, 1323-1331.

22 J. L. Sessler, P. Anzenbacher, H. Miyaji, K. Jursíková, E. R. Bleasdale, \& P. A. Gale, Ind. Eng. Chem. Res., 2000, 39, 3471-3478.

23 G. Gil-Ramírez, E.C. Escudero-Adán, J. Benet-Buchholz, P. Ballester, Angew. Chem. Int. Ed., 2008, 47, 4114-4118.

${ }^{24}$ P. T. C. Harrison, J. Fluorine Chem., 2005, 126, 1448-1456.

${ }^{25}$ A. Chmyrov, T. Sandén and J. Widengren, J. Phys. Chem. B, 2010, 114, 11282-11291.

${ }^{26}$ S. Huang, R. J. Clark and L. Zhu, Org. Lett., 2007, 9, 4999-5002.

${ }^{27}$ D. Landy, in Cyclodextrin Fundamentals, Reactivity and Analysis, eds. S. Fourmentin, G. Crini and E. Lichtfouse, Springer International Publishing, Cham, 2018, 223-255.

${ }^{28}$ (a) A. Brunelle, D. Touboul, O. Laprévote, J. Mass Spectrom., 2005, 40, 985-999; (b) M. Noun, E. Van Elslande, D. Touboul, H. Glanville, S. Bucklow, P. Walter and A. Brunelle, J. Mass Spectrom. 2016, 51, 1196-1210.

${ }^{29}$ R.N.S. Sodhi, Analyst, 2004, 129, 483-487. 